\title{
Permasalahan dan Upaya Pengentasan Kemiskinan di Pedesaan
}

\author{
Oleh : Imam Nurhidayat
}

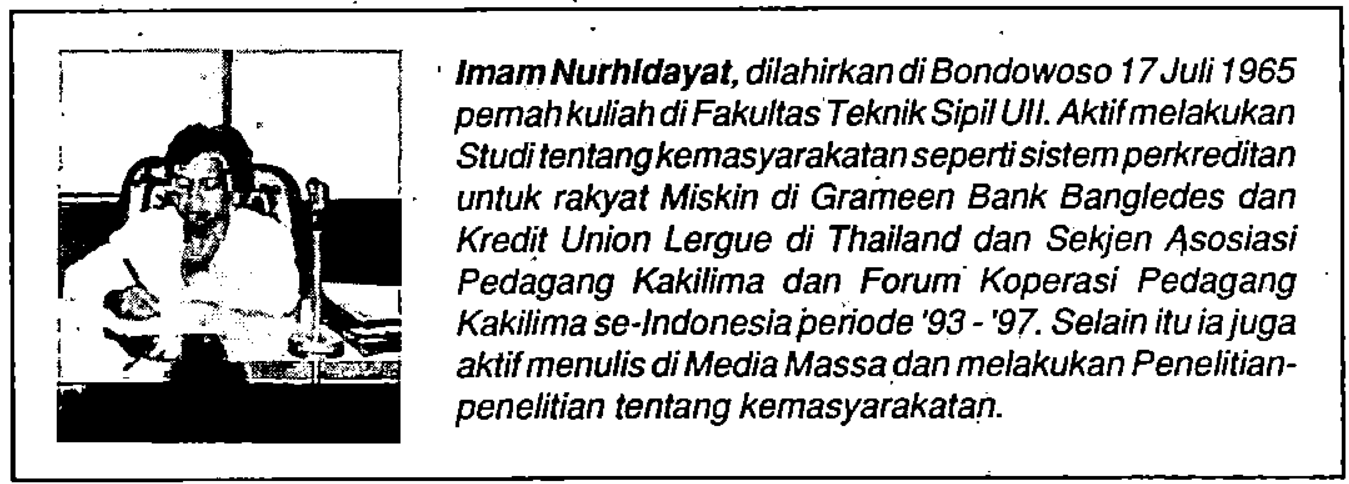

Pendahuluan

Pusat Peranserta Masyarakat menaruh keprihatinan dan kepedulian terhadap keseluruhan permasalahan struktural dan kultural, yang secara garis besardapat dicirikandalam 2 permasalahan pokok.Pertama, permasalahan kemiskinan danketerbelakangan yang masih mewamai kehidupan sebagian besarrakyat, serta telah merasuk dalam tata bilai dan sistem/struktur kemasyarakatan dan telah menciptakan situasi batas budaya kemiskinan. Menganggap kemiskinan sebagai suatu realitas ekonomi mikro saja merupakan simplifikasi yang berlebihan, seolah-olah masalah yang telah mensejarah ini bisa diatasi dengan cukup melalui pembinaan permodalan; ketrampilan, dan manajemen. Masa miskin inilah yang selalu tertinggal dari proses pembangunan dan modernisasi serta sering mengalami keterasingan (alienasi), penekanan (dominasi), perjinakan (domestikasi), pengikisan (likuidasi), pencerabutan (marginalisasi) dan pendesakan oleh sektor mapan perkotaan (gentrifikasi) (PPM, 1985).

$K e d u a$, rapuhnya penjembatan hubungan antarsub kultur, khususnya antar etnik, antar ruang, antar lapis dan antar corak penghayatan keagamaan.

Pembahasan berikut ini lebih menekankan pada permasalahan pertama yang sejak awal merupakan komitmen perjuangan PPM. Catatan kaki berikut ini merupakan sebagian kerangka kerja Pusat Peranserta Masyarakat (PPM) terutama dalam menangani masalah kemiskinan khușusnya di pedesaan.

Keadaan Sosial dan Ekonomi

Saat ini keadaan sosial ekonomi masyarakat masih ditandai oleh 
pertambahan penduduk yang cukup pesat, sebagianbesarmasih tergantung pada sektor pertanian dan pedesaan tradisional. Dalam situasi tanah pertanian yang sempit, maka rata-rata pemilikan lahan pertanian per rumah tanggan tani sangat menyedihkan. Diperkirakan terdapat 1,5jutarumahtangga tani yang tidak memiliki tanah sama sekali atau memiliki tanah yang kurang dari 500 meterpersegi.Situasi pemilikan sawah yang tidak menguntungkan ini menyebabkan kemiskinan dan pemiskinan massal, dimana rumah tangga tani yang memiliki tanah sawah sekitar 0,5 ha sampai 0,25 ha masih dapat disebut "mampu".

Berbagai upaya telah dilakukan oleh pemerintah untuk mengurangi dampak keterbatasan faktor produksi pertanian dan tanah diantaranya melalui transmigrasi dan pengembangan pekerjaan non pertanian di pedesaan. Sementara itu penduduk yang harus mempertahankan hidupnya banyak juga yang mengambil jalan pintas untuk menolong dirinyasendirimelalui urbanisasi ke kota.

Penduduk yang tetap tinggal di Pedesaan harusbersediahidup dalam situasi subsistensi dan involutif. Lapangan kerja pertanian telah sangat terbatas, sedangkan pekerjaan pertanian sendiri diperkirakan memiliki marginalitas produksi mendekati nol jika tidak malah negatif. Mereka masih bertahan di sektor ini semata-mata karena alasan yang bersifat non ekonomis. Alasan non ekonomis juga terlihat pada sebagian besar pekerja yang bergerak di bidang non pertanian pedesaan. Pekerjaan terakhir ini berkembang cukup pesat di pedesaan disebabkan karena banyak penduduk yang tergeser dari sektor pertanian, bukan karena alasan ekonomi bahwa sektor ini menguntungkan. Pelajaran yang dapat diperoleh dari perkembangan pekerjaan non pertanian di pedesaan beberapa negara sedang berkembang, ialah semakin tinggi sumbangan sektor ini dalam kehidupan pedesaan cenderung menggambarkan semakin buruknya situasi pertanian, sedikitnya demikian gejala pada awal perkembangan sektor ini.

Teknologi pedesaan, meliputi teknologi pemilihan jenis komoditi ekonomis pertanian, pasca panen, pengolahan hasil pertanian dan non pertanian masih belum berkembang. sedikitnya baru mungkin terserap oleh kalangan menengah ke atas saja. Arus informasi teknologis miripdengan nasibnya berbagai paket input pertanian modem, khususnya melalui program Bimas/Inmas yang hanya menguntungkan petani yang memiliki tanah layak. Akibat berlangsungnya proses pembangunan yang lebih mengejar surplus pedesaan dari pada konsumsi pedesaan ini, maka diperkirakan 60\% penduduk pedesaan hanya memperoleh $20 \%$ dari seluruh pendapatan pertanian, sedangkan golongan kaya yang besarnya hanya $20 \%$ memperoleh $60 \%$ dari seluruh pendapatan pertanian di pedesaan.

\section{Lingkaran Masalah}

Pada umumnya para ahli hanya membatasi diri untuk melakukan kajian teoritik tethadap tematik makro maupun mikro sekitar kemiskinan. Prasangka teoritik akan selalu menghadang upaya menyingkapaspek praktis keusahaan dalam situasi desa yang semakin dan sedang berlangsung proses pemiskinan, apalagi jika penyuguhan bersifat skematis dan dimaksudkan untuk mengambil kcputusan. 
Dengan menghadapi resiko ini, berikut ddiajukan catatan dari lapangan tentang 10 permasalahan ekonomi-keusahaan yang menyebabkan kemiskinan di pedesaan berdasarkan pengalaman pengembangan masyarakat yang dilakukan Pusat Peranserta Másyarakat (PPM) dalam 15 tahun terakhir di 1500 lokasi pengembangan masyarakat, yakni.

\section{Masalah etos/nilai}

Kemiskinan yang berjalan dalam ruang dan waktu yang luas/panjang dan telah mewamai pengalaman kesejahteraan berjuta-juta penduduk, telah menyebabkan kemiskinan diterima sebagai bagian syah dari hidup, dan mewamai hampir dari keseluruhan sistem nilai dan struktur sosial masyarakat. Kemiskinan diterima sebagai keniscayaan yang tidakperlu dipertanyakan lagi. Setiap usaha melawan kemiskinan, bukan saja akan menjadi pekerjaan yang tidak mudah, tetapi juga akan dipandang sebagai tindakan yang aneh dan mungkin "asisial". Dalam situasi budaya kemiskinan seperti ini, maka.gejala kemiskinan tidak cukup dilihat sebagai fungsi keterbatasan lapangan kerja, pendapatan, pendidikandan kesehatan saja, melainkan juga adanya suatu kenyataan bahwa "mereka miskin terhadap arti kemiskinan itu sendiri".

Moral subsistensi danupaya involutif menandai bentuk pengucapan praktis masyarakat, yang bertolak dari semangat dasaryang fatalistik, rasa ketidakmampuan (powerless), orientasi kemasa lampau, serta rasa adanya kejarangan sumber yang mampu memberi ganjaran selain dari Tuhan. Suatu semangat keagamaan (teologi) yang fatalistik dan kehilanganelan kekhalifahan.

2.Keterbatasan Pemilikan Faktor Produksi
Surplus pemilikan faktor produksi khususnya tanah pertanian, yang ditandai sekitar sepcrempat rumah tangga tani tidak memiliki tanah sawah sama sekali atau memiliki dalam jumlah yang sangat tidak berarti (kurang dari 0,50 ha).

\section{Surplus Tenaga Kerja}

Surplus tenaga kerja dengan keterampilan teknis dan manejemen yang terbatas, karena keterbatasan berlatih (bukan keterbatasan pendidikana). Sebagian besar tenaga kerja (penduduk usia produktif 10 th ke atas) sedang menganggur dalam berbagai variasi pengangguran.

\section{Keterbatasan Lapangan Kerja}

Keterbatasan lapangan kerja disektor pertanian, baik akibat keterbatasan tanah pertanian maupun akibat keterbatasan karena masuknya input pertanian modem, sementara itu lapangan pekerjaan non pertanian belum cukupdidukung olch tradisi keusahaan desa. Walaupun tenaga kerja paling banyak di sektor pertanian $(55,9 \%)$ tetapi hampir separuh $(41,5 \%)$ pekerja ini beberja pada keluarga yang tidak dibayar.

\section{Keterbatasan Teknologi .}

Keterbatasan teknologi pemilihan komoditi pertanian yang bersifat ekonomis, teknologi paska panen dan pengolahan hasil pertanian, serta teknologi non tani. Masyarakat desa belum memiliki kebebasan untuk menentukan alternatif tanaman maupun teknologi pertaniannya, schingga produktivitas marginalnya rendah sekali. Mereka misalnya harus puas dengan menjual kacang ke kota dan kembali dengan membeli kacang telur dari kota, dengan selisih harga yang besar. Sementara itu, perkembangan lapangan kerja non tani juga belum didukung oleh teknologi yang memadai, atau masih bersilat kecil-kecilan 
dan sederhana sekali.

6. Keterbatasan Informasi, Pembinaan, Fasilitas Modal, Proteksi Usaha dan Kesempatan (opportunities)

Keterbatasan ịformasi,pembinaan, fasilitas modal, proteksi usaha dan kesempatan (opportunities), suatulingkaran yang lazim dalam bisnis modem. Hampir dalam setiap kegiatannya mereka harus melakukan secara swakarsa dan bersedia untuk harus puas dengan apa yang menjadi miliknya saja, tanpa berkeinginan untuk lebih dari pada apa yang mungkin. Sementara itu faktor produksi unggulan tersebut dikuasai oleh sektor perkotaan industrial terutama dalam wujud informasi, teknologi, dan fasilitas perkreditan.

\section{Nilaitukar perdagangan (term of trade)}

Nilai tukar perdagangan (term of trade) produk pedesaan lebih rendah dibanding/terhadap produk perkotaan atau sektor modem. Orang desa harus menjual barangnya terlalu murah ke kota dan membeli barang dari kota terlalu mahal. Hal ini secaralangsungmenyebabkan orang desa kurang memperoleh surplus yang berarti hampir dalam semua lapangan pekerjaan yang ia lakukan, sehingga hampir tidak mungkin baginya melakukan akumulasi kapital. Hal ini dapat dilihat dari rendahnya nilai tukar petani (NTP).

\section{Terbatasnya uang yang beredar}

Terbatasnya uang yang beredar di pedesaan, merupakan fungsi dari terjadinya produktivitas marginal yang nol dan terbatasnya fasilitas kredit resmi yang masuk ke desa. Sebagian besar penduduk pedesaan jika memerlukan kredit untuk tambahan modal mencarinya dari salurán kredit non institusional lebih-lebih bagi mereka yang berasal dari kalangan miskin.

\section{Kebijaksanaan Pemerintah}

Kebijaksanaan pemerintah yang lebih menitik beratkan pada laju pertumbuhan ekonomi, tetapi ternyata berakibat tidak ringan kepada masyarakat pedesaandan umumnya masyarakatmiskin perkotaan. Begitu juga kebijaksanaan pengembangan sektor pertanian yang lebih dititk beratkan pada peningkatan surplus produksi untuk mengejar swasembada pangan nasional dan kurang mengacu pada pemenuhan konsumsi pedesaan saja, menyebabkan sektor pedesaan/pertanian cenderung bertugas menyangga stabilitas ekonomi nasional, khususnya untuk menunjang kehidupan perkotaan, dengan kebebasan yang terbatas untuk menentukan pilihan ekonomis.

\section{Belum berfungsinya kelembagaan} swadaya masyarakat

Belum berfungsinya kelembagaan swadaya masyarakat di pedesaan yang menampung prakarsa, peraserta dan swadaya masyarakat, untuk menolong dirinya sendiri, membangun dirinya sendiri dalam bidang sosial ekonomi. Setidaknya, kelembagaan yang ada masih kurang fungsional dan/atau tingkat swadayanya rendah. Kelembagaan yang dimaksud bukan saja diharapkan mampu mengembangkan kegiatan pemenuhan dan penyantunan minat dan kebutuhan sosial ekonomi masyarakat, melainkan juga mampu memproses menjadi infra struktur kemasyarakatan.

Melihat kaitan antar masalah yang sangat erat ini, sebanrnya akan sukar menarik kesimpulan masalah mana yang paling diutamakan. Dalam kenyataannya, kesepuluh masalah dialas dapat dikelompokkan dalam 3 golongan, yaitu (i) 
masalah sistem nilai-etos dan kelembagaan infrastruktur; (ii) masalah struktural, khususnya keterbatasan faaktor produksi tanah pertanian dan ketenagakerjaan yang melimpah; dan (iii) masalah kebijaksanaan dan pendekatan model pembangunan.

\section{Pilihan Kebijaksanaan}

Dasar pertimbangan dalam pemilihan altematif ini ialah: $P$ crtama, pada dasamya suatu perkembangan masyarakat baru akan berarti secara kultural jika ditandai dengan perkembangan selùruh aspek kehidupan yang mendukung masyarakat tersebut. Keseluruhan aspek kehidupan ini menunjuk pada aspek arus bawah (sistem nilai dan/atau aspek suprastruktur), aspek tengah (infrastruktur) dan aspek arus atas (cara-cara masyarakat memenuhi kepentingan dan kebutuhannya).

Kedua, betapapun secara teoritik dapat diterima anggapan bahwa perilaku aspek arus atas sangat tergantung pada konstelasi aspek arus bawah dan tengah, namun sukar dapat dibayangkan suatu perubahan akan berhasil jika dimulai dengan upaya untuk menata atau merubah anus bawah. Langkah terakhir ini bukan saja akan mengundang prasangka, melainkan juga menghianati kenyataan teoritik bahwa aspek arus bawah ini sangat kental, sukar berubah dan produk sejarah yang panjang.

Ketiga, kemungkinan yang memberi harapan dalam proses perubahan budaya (termasukbudayakemiskinan) ialah melalui pengembangan aspek arus ataske arah yang fungsional dan bermasa depan (prospektif), melalui langkah kecil-kecilan dalam rentang waktu yang panjang. Pada saatnya perilaku arus atas yang baru ini akan mengisi proses belajar masyarakat (learning society), sedemikian rupa schingga berpengaruh terhadap aspek arus bawah.

Keempat, langkah pengembangan arus atas ini akan efektif jika memenuhi syarat kepanjangan (time) dan kelcluasaan jangkauan(magniludo), disamping schagai fungsi swadayamasyarakat itu sendiri. Oleh karena itu alternatif yang dipandang strategis ialah melalui penggalangan. kelembagaan penampung prakarsa, peranserta dan swadaya masyarakat untuk pengempangan "sosial dan ekonomi. Kelembagaan swadaya fungsional (LS/F) ini dalam jangka panjang ak an berkembang menjadi pratata kemasyarakatan, yaitu suatu keadaan dalam mana masyarakat dapat mengembangkan perilaku alternatif (kelompok marginal) di tengah-tengah tradisi yang tidak senantiasa mendukung. Pranata ini pada saatnya aḳan berkembang menjadi pranata yang lain akan mendukung suatu komunitas.

Berdasarkan landasan pemikiran di atas, maka bidikan masalah dalam pengembangan masyarakat ini lebih diarahkan pada masalah pengembangan kelembagaan LS/F. Salah satu bentuk LS/ Fialah Usaha Bersama (UB) atau Koperasi, seperti yang dimaksud pasal 33 UUD 1945 , atau asosiasi-asosiasi.

\section{Penggalangan LS/F}

Dalam arti luas, pengembangan masyarakat merupakan suatu paket' kegiatan, termasuk didalamnya kegiatan pengkajian, penelitian, penggalangan dan pengembangankelembagaan, yang masingmasing kegiatan ditandai ạdanya masukan, peralatan dan metodologi. Perilaku berbagai kegiatan diatas sangat tergantung pada wawasan yang dipilih. Berikut ini akan 
diketengahkan serba sedikit tentang wawasan, pendekatan dan metodologi pengembangan masyarakat dan penggalangan LS/F yang dikembangkan oleh PPM.

Penggalangan LS/F dalam kerangka proses perubahan kebudayaan dan/atau gerakan kebudayaan selalu berarti sebagai upaya untuk menciptakan keadaan (pensituasian) agar masyarakat dapat mengembangkan prakarsa, peranserta dan swadaya dalam menolong diri sendiri. Hal ini menghendaki arti, bahwa pembangunan dan pengembangan masyarakat bukan sebagai kerja "untuk" rakyat, bukan juga diartikan sebagai "bersama" -rakyat, melainkan sepenuhnya harus berarti "darioleh-untuk" rakyat. Selain cara ini, sangat mungkin suatu pengembangan masyarakat dapat membantu memajukan salah satu aspek dari kehidupan masyarakat, sementara aspek yang lain tidak berubah atau lebih lambat perubahannya. Dengan kata lain wawasan ini menghendaki bahwa melalui proses pengembangan masyarakat yang bersifat swadaya mumi ini, maka setiap perkembangan dan pencapaian masyarakat merupakan bagian dari momentum kemasyarakatan itu sendiri. Momentum ini berarti keadaan kumulatif dan berfungsinya keseluruhan aspek kehidupain secara serentak, utuh dan akrab bagi seluruh anggota masyarakat.

Sebagai misal, pada suatu daerah masyarakat mengeluh tiak memiliki modal untuk usaha. Cara yang paling baik bukan dengan memberikan bantuan modal untuk mercka agar berusaha, melainkan dengan menciptakan keadaan agar mereka dapat memenuhi kebutuhan modalnya secara apa yang bisa ia lakukan. Misalnya yang dikembangkan PPM bersama Direktorat Bangdes Propinsi DIY dalam 'rangka monetasi pedesaan dalam bentuk pengembangan Lembaga Perkreditan Rakyat Swadaya di 550 dusun yang saat ini anggotanya telah mencapai 25.000 orang. Di suatu daerah lain masyarakàt mengeluh tidak ada air. Barangkali soal ini bukan karena tidak ada air, melainkan mereka belum cukup dalan menggali sumur, taruh saja sumur sudah digali tetapi tidak ada sumbernya., masalahnya terletak bagaimana mengambil air dari jarak jauh. Dalam pengembangan masyarakat, bukan bagaimana membantu penduduk untuk membuat sumur atau mengadakan pompa hidrolic-ram, masalahnya adalah bagaimana menciptakan kondisi (pensituasian) agar masyarakat mampu menggali sumur dan/atau mengadakan pompa hidran secara apa yang bisa ia lakukan. Berapa banyak paket teknologi dari pemerintah maupun LSM yang hanya seumur jagung padahal secara riil masyarakat membutuhkan teknologi tersebut.

Pendekatan ini jelas berusaha menciptakan keadaan agarmasyarakat bisa menjadi subyek perubahan, subyek budaya bagi dirinya sendiri. Sebab, masalah kemiskinan bukan soal rendahnya pendapatan, terbatasnya lapangan kerja, rendahnya $\mathrm{kwalitas}$ hidup/kesehatan masyarakat dan pendidikan, melainkan persoalan budaya. Persoalan sistem nilai, struktur kemasyarakatan dan aspek-aspek tingkah laku tersebut. Segala bentuk belas kasihan (karikatif) dan pertolongan pasti tidak menyelesaikan, setidaknya hal ini harus diletakkan dalam kerangka metodologis gerakan kebudayaan (jadi 
bukan hanya soal timing).

Cara yang dipandang mungkin dan efisien untuk melancarkan gerakan kebudayaan tersebut melalui pelembagaan masyarakat untuk menjalankan kegiatankegiatan swadaya dan fungsional. LS/F ini diarahkan untuk mampu berkembang menjadi "pranata". (institusi) kemasyarakatan, dan bersama pranata kemasyarakatan lain akan menyangga kehidupan masyarakat.

Sejak penggalangan $\mathrm{LS} / \mathrm{F}$ ini harus secara konsisten diupayakan sebagai fungsi dari usaha masyarakat sendiri dan dalam perkembangannya kemudian harus sepenuhnya tegak diatas prinsip swadaya, serta berkembang kearah "biasa". Ia hadir seperti hadirnya Kalurahan untuk memenuhi kebutuhan administrasi publik, seperti hadiriya masjid untuk ibadah, seperti hadimya sekolah untuk pendidikan anak, seperti hadimya jalan raya untuk sarana hubungan, last but not least LS/F hadir sebagai pranata atau pusatpelayanan publik (public service) untuk menampung kepentingan sosial ekonomi masyarakat.

Lembaga swadaya fungsional yang dikembangkan PPM kini tersebar di 23 provinsi pada 1500 lokasi pengembangan masyarakat diantaranya Asosiasi dan Koperasi Pedagang Kakilima se-Indonesia (Jateng, DIY, DKI Jakarta, Jatim, Sulsel, Sumut, Irian Jayà, dil), Asosiasi peranserta Pedagang Pasar, Usaha Bersama (sebanyak 560 kelompok), Koperasi Pedagang Keliling Jakarta, dan lain-lain.

\section{Penutup}

Dalam rangka IDT PPM telah mengajukan konsep pengembangan kepada pemerintah DIY terutama model pendekatan yang harus dikembangkan adalah model interaksi ekonomi praktis. Kelompok Swadaya Masyarakat yang digalang hàruslah menjadi LS/F ckonomi mumi yang dikelola secara bisnis dengan disiplin yang keras. Hanya dengan demikian mentalitas ekonomi rakyat miskin akan terbangun. PPM mempunyai Adagium: jangan beri seseorang itu ikan, sebab dia hanya bisa makan sehari saja. Tapi, tak perlu jüga diberi pancing, sebab belum tentu ia suka memancing, atau yang pasti, dia bukan anakkita. Yang bisa kita lakukan ialah bantulah mereka meraih harga diri dan tanggung-jawab sendiri.

\section{Daftar Pustaka}

Gunawan Sumahadiningrat. Kiat menghindari, Mulut Buaya, Tempo, Jakarta, 12 Maret 1994.

Muliyanto, Dari Program Stabilitas sampai kebijaksanaan Pembangunan Berkelanjutan, Makalah Seminar Nasional Analisa Antarena Pembangunan Ekonomi Indonesia, Yogyakarta, 25 Marel 1994.

Mubyarto Dkk, Keswadayann Masyarakat Desa Tertinggal, Aditya Media. Yogyakarta, 1994.

Pusat Peranserta Masyarakat. Sekapur Sirir PPM. Jakarta. 1989.

, Proposal Pelaksanaan IDT 93/94, Yogyakaurta, 1994 